\title{
Cell Membrane Stability and Relative Water Content of Cymbopogon citratus (Lemon Grass)
}

\author{
H. M. Maishanu ${ }^{1^{*}}$ and A. M. Rabe ${ }^{1}$ \\ ${ }^{1}$ Department of Biological Science, Usmanu Danfodiyo University Sokoto, Sokoto State, Nigeria.
}

Authors' contributions

This work was carried out in collaboration between both authors. Author HMM designed the study, performed the statistical analysis, wrote the protocol and wrote the first draft of the manuscript. Authors HMM and AMR managed the analyses of the study. Author AMR managed the literature searches. Both authors read and approved the final manuscript.

\author{
Article Information \\ DOI: 10.9734/ARRB/2019/v33i230114 \\ Editor(s): \\ (1) Paola Angelini, Department of Applied Biology, University of Perugia, Perugia, Italy. \\ Reviewers: \\ (1) Ufuoma Bigila Shemishere, Federal University Birnin Kebbi, Nigeria. \\ (2) J. Dario Aristizabal-Ochoa, Universidad Nacional de Colombia, Colombia. \\ (3) Monika Marković, University of Josip Juraj Strossmayer in Osijek, Croatia. \\ Complete Peer review History: http://www.sdiarticle4.com/review-history/51483
}

Method Article

Received 10 July 2019

Accepted 12 September 2019

Published 20 September 2019

\begin{abstract}
In this research the cell membrane stability (CMS), relative water content (RWC) and effect of different water interval on Cymbopogon citratus (lemon grass) was assessed. The cell membrane stability and relative water content of the plant shows the physiological activity of the plant. The plant sample was subjected to three different watering regimes viz: one, two- and three-days intervals with a control sample irrigated daily for a period of twelve months. Uniform stalk of lemon grass plants were planted into a depth of $7.5 \mathrm{~cm}$ composted soil, each treatment was made in triplicate. The evaluated growth parameters where height of the plant, number of leaves and tillers, which were taken weekly for period of twelve months (year). The height shows a significant difference from first to twelfth month after planting. The height of the plant increases simultaneous with the age of the plant. First month after planting show significant difference in height of sample watered daily and treated samples. The results shows that the RWC (07.14\%) and CMS (52.58\%) was low in samples under water stress respectively when compared to well-watered samples $(55.41 \%)$. No significant difference was observed between samples under one, two and three days interval. The number of leaves differs significantly in the first MAP except in the samples watered daily and three days interval. Maximum number of leaves was achieved at twelfth MAP under one
\end{abstract}


day interval (137.33) followed by samples watered daily (126) and two days interval, while three days interval has the least number of leaves (leaf number). The number of tillers shows significant differences between the means at fifth and sixth MAP, (fifth MAP = 73.33 and sixth MAP $=126$ ) and the treatments under one day intervals (fifth MAP $=18.33$ and sixth MAP $=35.67$ ). In the research, samples watered daily and under one day intervals shows high productivity when compared to the remaining treatment.

Keywords: Cymbopogon citrates; Month after Planting (MAP); Cell Membrane Stability (CMS); Relative Water Content (RWC); irrigation frequency.

\section{INTRODUCTION}

Drought leads to drastic lowering of water table in the vulnerable areas. It is identified among the major environmental problems faced in northern part of Nigeria. According to Ogundele [1] and Obi [2], the livelihoods in the affected area in this sub-region are heavily dependent on soil, water resources and part of vegetation resources. Mostly are affected with drought and human activities such as overgrazing, mono-cropping, lack or shortage of soil nutrients or manure. It affected the natural ecological equilibrium of the drought affected area. Variation in climate especially precipitation and temperature are major determining factors influencing desertification and drought in Northern Nigeria [2].

Global change in climatic conditions is one of the key factors responsible for increased drought coupled with increase population has lead to high demands for food production and energy which ultimately result to the abandoning of some economically important plants. Unfortunately, availability of water is a major environmental constraint faced in most communities of arid and Sudan savanna and most of the crops basically need water for their normal physiological activities for normal growth and productivity. This results to irrigation farming of ornamental and economic important plants in the area. Idea about the basic requirement of watering regime is not clear.

Grass can be grown and harvested on a marginal land, away from areas suitable for food crop [3]. They are one of the largest groups in plant kingdom. Dominating almost all available terrestrial ecosystems. The advantage of using grass crops is that they can grow on marginal lands (soils that can be in bad physical condition or which suffer from salt stress) [4]. Lemon grass is a turfted or compacted perennial crop having a characteristic scent of lemon with so many medicinal potential and economic values [5]. It is used as a culinary in Asia countries and as insect repellents [3]. The aim of this research is to determine effect of different irrigation frequency of Cymbopogon citratus (Lemon grass). The objectives are to assess the effect of three watering regimes (one-, two- and three-days interval) on the growth parameters (leaf and tillers number) and productivity of $C$. citratus (Lemon grass).

\section{MATERIALS AND METHODS}

\subsection{Study Area}

The study was conducted within the premises of the Main campus, Usmanu Danfodiyo University, Sokoto $\left(13^{\circ} 06^{\prime}-13^{\circ} 08^{\prime} \mathrm{N}, 5^{\circ} 11^{\prime}-5^{\circ} 12^{\prime} \mathrm{E}\right.$ and $350 \mathrm{~m}$ above sea level. It has about 70-125 days of rainy season and the rest as long dry season of the year [6]. Annual rainfall is not only variable and unreliable, but a mere fraction of the potential evapo-transpiration. The mean annual rainfall is $700 \mathrm{~mm}$ per annum, falling between the months of June and October. The harmattan season stretches from November to March, with dry and dust laden wind [6].

Sokoto state has a maximum temperature of $45^{\circ} \mathrm{C}$ and minimum of $10^{\circ} \mathrm{C}$ in April and January respectively. Temperatures are variable during the dry and rainy season. The minimum temperature range is $10-23^{\circ} \mathrm{C}$ and the maximum is between $33^{\circ} \mathrm{C}-45^{\circ} \mathrm{C}$. Annual average temperature has a minimum of $22.90^{\circ} \mathrm{C}$ and a maximum of $35.98^{\circ} \mathrm{C}$. Relative humidity during the rainy season is between $52 \%$ $56 \%$ and below $28 \%$ in the dry season (SERC, 2016).

\subsection{Samples Collection}

Thirty pieces of $15 \mathrm{~cm}$ vegetative stalk of lemon grass were obtained by cutting the stalk with blade from different plants. The species were authenticated by comparison with preserved specimen in the University Herbarium (Usmanu Danfodiyo University, Sokoto). 


\subsection{Grass Cultivation and Induction of Water Stress}

Stalks of lemon grass were planted directly into a depth of $7.5 \mathrm{~cm}$ in plastic pots with an area of $12.57 \mathrm{~cm}^{2}$ containing composted garden soil. It was then watered for a period of one week to acclimatize before imposing the treatments.

\subsection{Induction of Irrigation Frequency}

After two weeks of transplanting, irrigation frequency was imposed by reducing the amount of irrigation water per pot and irrigation frequency per week. Three watering regimes were constituted and the plants therefore formed into three groups. The first group was watered after three (3) days, the second group was watered after two (2) days and the third group was watered after one day interval. All with one litre per irrigation event. Each group was replicated three (3) times. This gives a total of three experimental set-ups by three replications by three plants.

\subsection{Growth Evaluation}

The growth of the $C$. citratus was evaluated each week, for a period when the plants are expected to reach vegetative growth. The evaluated growth parameters are plant height $(\mathrm{cm})$, number of leaves and tillers per plant.

\subsection{Assessment of Physiological Properties of C. citrates}

The physiological properties of the grasses ( $C$. citratus) assessed are the relative water content (RWC) and cell membrane stability (CMS) as follows:

\subsection{Relative Water Content of the Plant (RWC)}

Leaf samples were detached from the main plant and immediately weighed to determine the fresh weight (FW). Samples were placed into covered petri dishes filled with water for the leaves to reach full hydration. After approximately 24 hours in a freezer under $4^{\circ} \mathrm{C}$ leaf samples were blotted dry with paper towels and weighed to determine turgid weight (TW). Leaf tissues were then dried in an oven at $80^{\circ} \mathrm{C}$ for 48 hours to determine dry weight (DW). Leaf RWC was calculated as: (FWDW $) /(T W-D W) \times 100$ [7].

\subsection{Cell Membrane Stability}

The cell membrane stability was assessed by measuring the electrolyte linkage for ten seconds for each of the treatment (well-watered and stressed samples). Exactly $0.5 \mathrm{~cm}$ long leaves of each of the treatment were incubated in $5 \mathrm{ml}$ distilled deionized water, it was then placed on a shaker for 24 hours. The conductance of the incubation solution was measured as the initial electrolyte leakage $\left(\mathrm{C}_{\mathrm{i}}\right)$ using a conductance meter. Leaf tissue in the solution was autoclaved at $120^{\circ} \mathrm{C}$ for 30 minutes in order to kill the leaf tissue. The conductance of the incubated solution of the autoclaved tissues samples $\left(\mathrm{C}_{\max }\right)$ was determined following $24 \mathrm{~h}$ incubation on a shaker with Slight Modification of $[7,8]$. Relatively electrolyte conductance was calculated as $\left(\mathrm{C}_{\mathrm{i}} / \mathrm{C}_{\max }\right) \times 100[7,8]$.

\subsection{Experimental Design and Data Analysis}

Complete Randomized Design (CRD) was used for the experimental design. The data obtained were subjected to Analysis of Variance (ANOVA) and means that are significant were separated using Duncan at $5 \%$ level of significance.

\section{RESULTS AND DISCUSSION}

Relative water content and membrane stability in Table 1 shows the physiological activities of the grasses. The result shows $90 \%$ relative water content in all the well-watered samples of $C$. citratus. Water stress affects the growth activities, number of leaves and tillers of $C$. citratus. This is in agreement with [9] observations that water stress has an adverse effect on main aspect of plant physiology, especially photosynthetic capacity. If the stress is prolonged the plant growth and productivity are negatively affected. This determines the development of plants, increase survivability and growth. Although, [10,11] pointed out that plant developed various mechanisms to reduce their consumption of resources and adjust their growth to adverse environmental conditions.

Mahmoodian [12] reported plant performance under water stress affecting various physiological processes associated with growth, development and economic yield of a crop [13]. Water deficits disturb normal turgor pressure and the loss of cell turgidity may stop cell enlargement that 
causes reduced plant growth. It decreases leaf area index. Economic important crops such as maize, wheat, rice barley belonging to poeacea family and other food crops are affected by changes in water potentials at important stages [14]. In the field water deficits do not act alone, but also with high temperature and high light stressed [15].

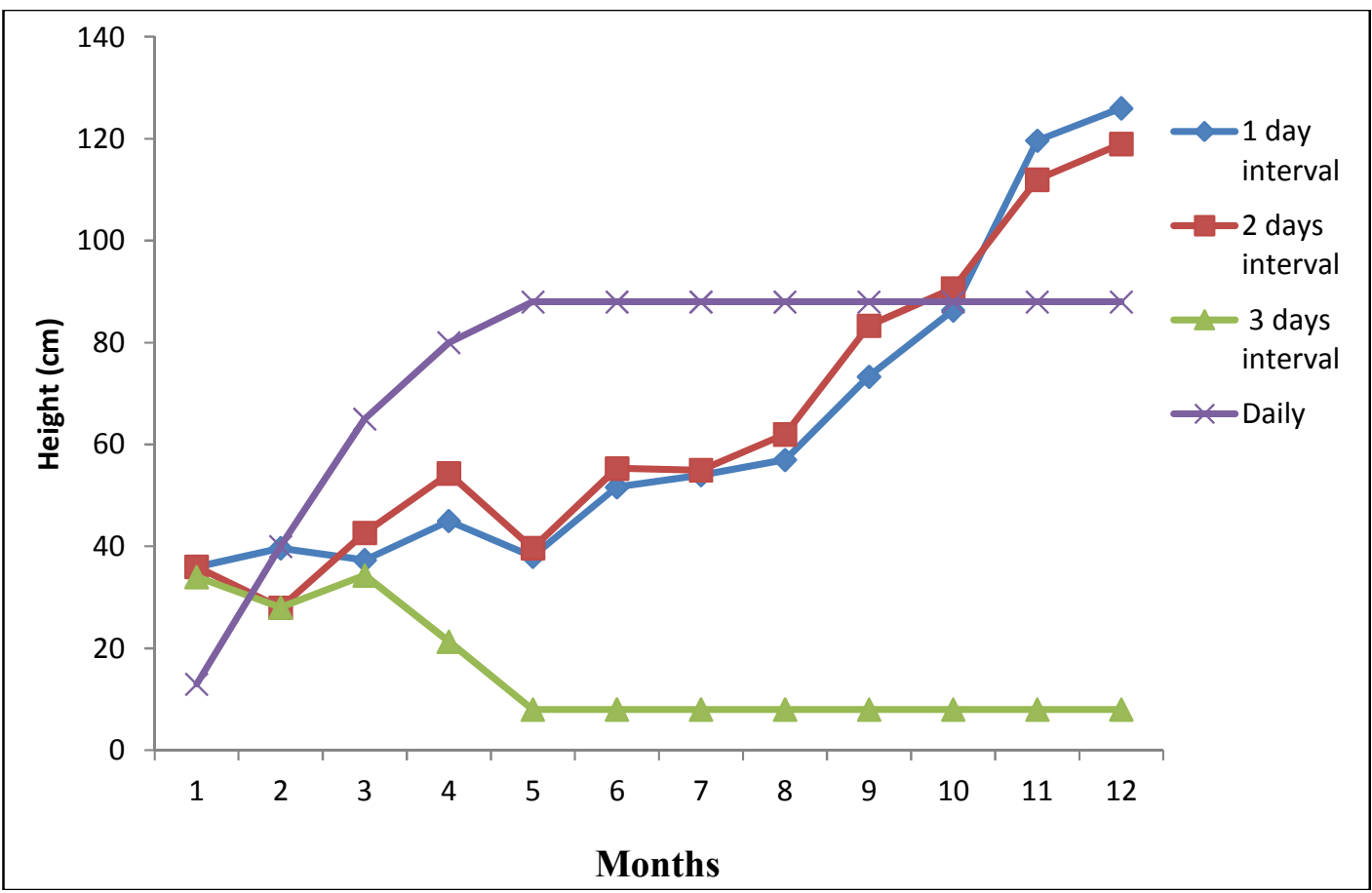

Fig. 1. Effect of different irrigation frequency on the height of $C$. citratus

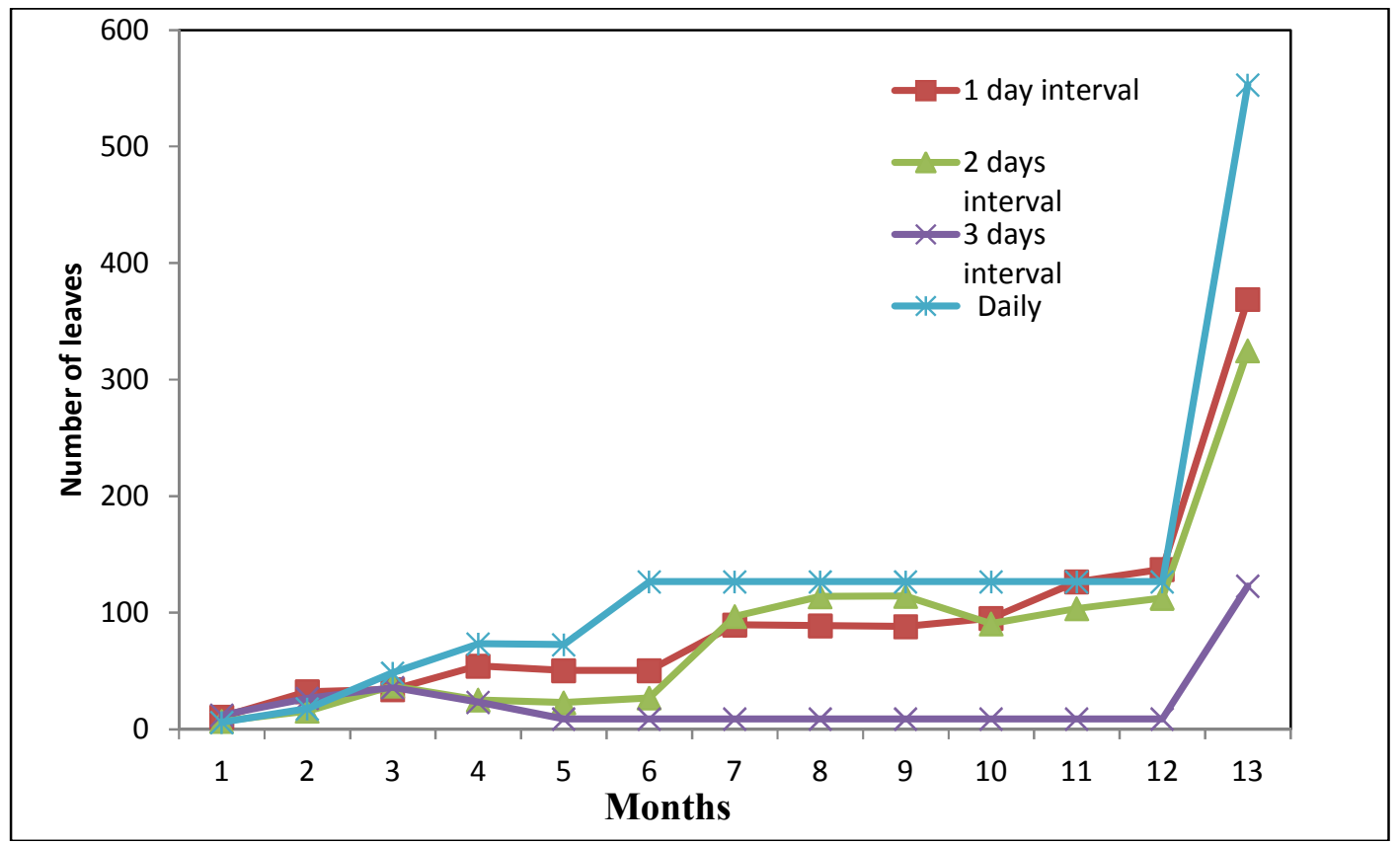

Fig. 2. Effect of different irrigation frequency on the leaves of $C$. citratus 


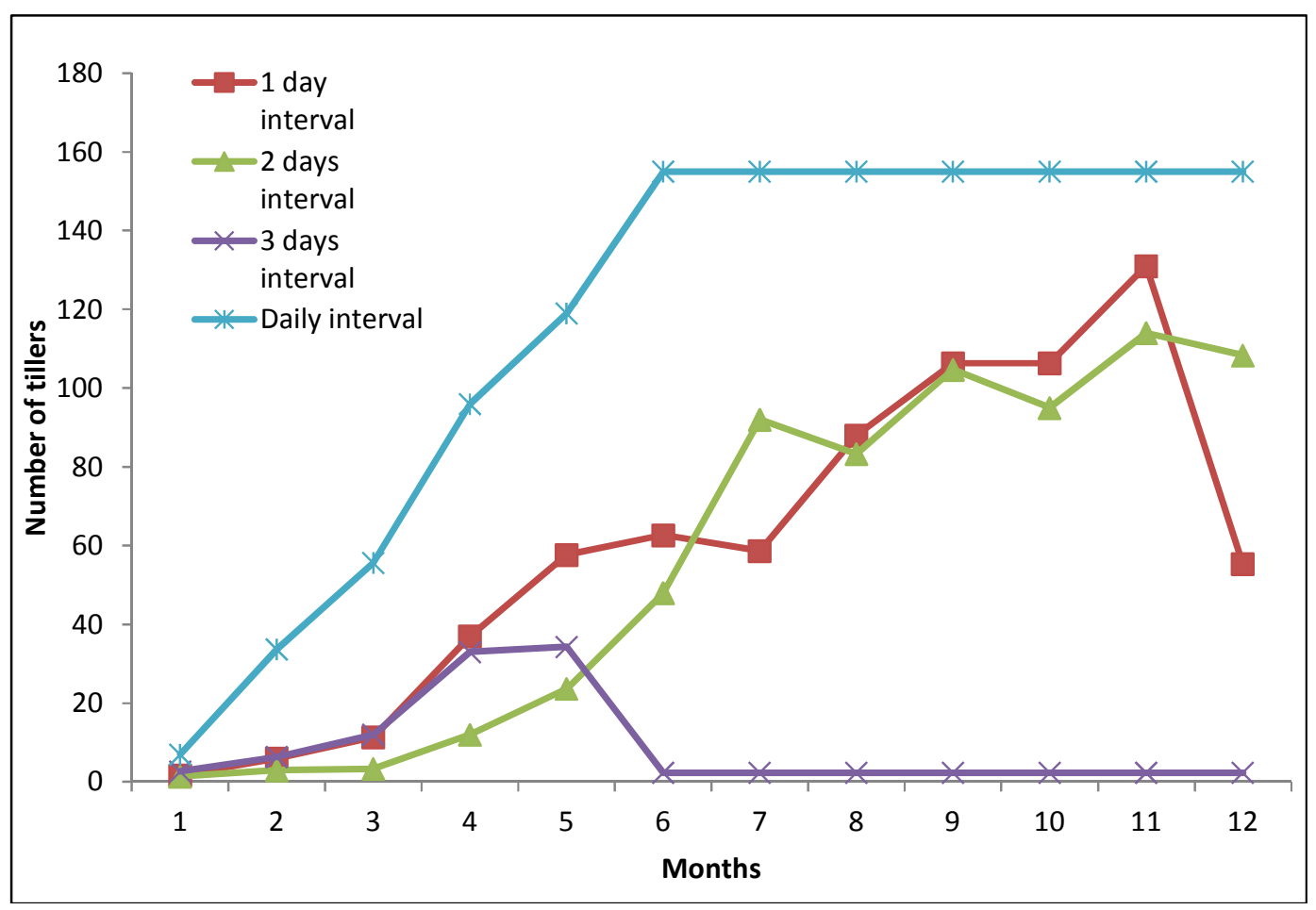

Fig. 3. Effect of different irrigation intervals on the tillers of $\boldsymbol{C}$. citrates

Table 1. Physiological properties of C. citrates

\begin{tabular}{llll}
\hline S/No & Treatment & Relative water content $(\%)$ & Cell membrane stability $(\%)$ \\
\hline 1 & Well watered & $90.00^{\mathrm{a}}$ & $55.41^{\mathrm{a}}$ \\
2 & Water stressed & $07.14^{\mathrm{b}}$ & $52.58^{\mathrm{a}}$ \\
\hline \multicolumn{2}{c}{ Means followed by different super script in the same column are significantly different $(P<0.05)$ using one-way }
\end{tabular}
ANOVA

C. citratus which was transplanted, tend to acclimatized to the environment in the first week of planting. In the second week, the emergence of leaves from the stalk was noted. Looking at the stage of grass growth, three main stages were observed. The first stage shows a vegetative stage and second stage transition stage [16]. In the vegetative stage, favourable environmental condition plays an important part on the growth of the plant species. But in this research, different watering regime (water stress) was taken into consideration for the growth tolerance of the plant; samples irrigated daily shows fastest vegetative growth in the first three month of planting. This is in line with the rules of growth as described by Singh et al. [16] and Rabe et al. [17], who stated that during lag phase or second phase of growth, the growth rate is faster. Samples watered after two days and one day interval shows slight significant differences at all stages.
Water frequency has effect on the leaves productivity, as the water supplies is frequently adequate, the number of leaves produce tend to increase. The increase in the number of leaves determines the physiological activities of the species. Despite all other factors, water plays a greater role in activities such as food synthesis or production in the process of photosynthesis. The results obtained, during the first period of growth under all the watering regimes shows that the growth rate is slow with certain fluctuation in the number of leaves, this happens as a results of stress that happens at certain interval of growth as indicated in Figs 1, 2 and 3. During the period the number of leaves decreases within fourth and sixth MAP. This could be due to high intensity of light and temperature which resulted in high photosynthetic activity and evapo-transpiration within the plant samples. However, for the process to take place water is needed and the water level is lower than the basic requirements 
of the plant species. The water requirement in well watered sample is sufficient enough for the plant to carry out its physiological activities. These resulted in growth and productivity with an increase in leaf number. Moreover, due to sufficient water requirement of the sample irrigated daily, the highest number of leaves was obtained within sixth MAP. While water stress effect the number and vegetative growth of the leaves under two days intervals, extending longer than samples irrigated daily for a period of three month.

It was observed that in the beginning of fifth month, the grass samples watered after three-day intervals could not tolerate water stress; therefore, tend to wither in order to reduce loss of water to the environment because of the high temperature $\left(43^{\circ} \mathrm{C}\right)$, this is in agreement with observation of Chaves et al. [15] and Rabe et al. [17]. Although, all watering regimes, except for three-day interval, have high leaves production. This is an indication of efficient photosynthetic and physiological activities occurring within the grass samples ( $C$. citratus). On the other hand, it is also in line with [18] findings which show that long term water stress effects on metabolic reactions are associated with plant growth stage, water storage capacity of soil and physiological aspects of plant.

According to Rabe et al. [17], plant stress is impaired by severe drought stress due to a decrease in stomatal opening which limits carbon dioxides uptake and hence reduces photosynthetic activity. Plant growth was anchored by photosynthesis; however, excess light can cause severe damage to plants. Excess light induces photo-oxidation, which leads to increase production of highly reactive oxygen intermediates that negatively affect biological molecules, and if severe, a significant decrease in plant productivity [19]. Water stress is controlled by complex regulatory events such as Abscisic acids and activities of transcript factor that regulates the opening and closing of the stomata which enables the plants to adapt and survive [17].

The Agricultural productivity is affected by water deficiency in term of plant growth, life cycle and biomass accumulation. This result to reduction of rate of cell division, expansion, leaf size, stem elongation, root proliferation, disturbed stomata oscillations, plant water and nutrient relations with diminished crop productivity and water use efficiency [20].

\section{CONCLUSION}

In this research, samples irrigated daily yielded more followed by samples irrigated after one day and two days intervals. While samples under three days intervals couldn't sustain water stress. The yield and productivity of the grass samples tested was higher under samples irrigated daily and one day interval. Lemon grass being perennial plants, the seeds and inflorescent was not achieved in this research within the period of studies. Watering regime of two-day interval should be considered instead of one day interval.

\section{COMPETING INTERESTS}

Authors have declared that no competing interests exist.

\section{REFERENCES}

1. Ogundele SO. Indigenous knowledge systems in Central Nigeria. Indian Journal of Traditional Knowledge; 2006.

2. Obi NI. Desertification and drought risk vulnerability: Potentials of desertification and drought risk management in Northern Nigeria (A case of Sokoto, Kano and Kaduna). Journal of Environmental Management and Safety. 2012;3:42-55.

3. Amina RM, Aliero BL, Gumi AM. Phytochemical screening and oil yield of a potential herb, camel grass (Cymbopogon schoenanthus Spreng.) Central European Journal of Experimental Science. 2013;2 (3):15-19.

Available:http://scholarsresearchlibrary.co m/archive.html

4. Ranitha $M$, Abdurahman $H$, NourZiad $A$. Suleiman, Azhair H. Nour, Raj S. A comparative study of lemongrass (Cymbopogon citratus) essential oil extracted by microwave-assisted hydrodistillation (HD) method. International Journal of Chemical Engineering and Applications. 2014;5(2):104.

5. Anonymous. Cymbopogon citratus. Available:http://en.wikipedia.Org/wiki/Cymb opogon citratus

(Retrived on: 3/23/2010)

6. SERC. Sokoto Energy Research Center: Usmanu Danfodiyo University Sokoto, Sokoto State; 2016.

7. Liu SC, Jin JQ, Ma JQ, Yao MZ, Ma CL, Li CF, Zhao-Tang Ding, Liang Chen, MaC. Transcriptomic analysis of tea plant 
responding to drought stress and recovery. PLoS ONE. 2016;11(1):e0147306.

DOI:10.1371/journal.pone.0147306)

8. Zhou P, An Y, Wang Z, Du H, Huang B. Characterization of gene expression Associated with drought Avoidance and tolerance trait in a perennial grass species. PLoSONE. 2014;9(8):e103611.

Available:https://doi.org/10.1371/journal.po ne.0103611

9. Osakabe Y, Keishi O, Kazou S, Lam-so T. Response of plants to Water stress; 2014. Available:http//www.responseofplanttowate rstress.com

10. Nishiyama $R$, Watanaba $Y$, LeyvaGonzales MA, Vanha C, Fujita Y, Tanaka V. Arabidopsis AHP2, AHP3, AHP5 HistidinePhototransfer proteins function as reductant negative regulators of drought stress response. Proc. National Academic of Sciences U.S.A. 2013;110:4840-4845.

11. Ha CV, Leyva-Gonzaleez MA, Osakabe $Y$, Tran UT, Nishiyama R, Watanabe $Y$. Positive regulatory role of strigolactone in plant responses to drought and salt stress. Proc. National Academic of Sciences U.S.A. 2014;111:581-856.

12. Mahmoodian L, Naseri $R$, Mirzae $A$. Variability of grain yield and some important agronomic traits in Mungbean ((Vigina radiate L.) Cultivars as affected by drought stress. International Research Journal of Applied Basic Sciences. 2012;3 (3):486-492.

13. Allahmourdi P, Ghobadi M, Taherabadi S. Physiological aspects of mungbean in response to drought stress. Singapore International Conference of Food Engineering and Biotechnology. 2011;9.

14. Jogalah S, Govind SR, Tran LS. System biology based approaches toward understanding drought tolerance in food crops. Critical review biotechnology. 2012; 33:33-39.

15. Chaves MM, Percira JS, Maroco J, Rodriguues $\mathrm{ML}$, Pinheiro $\mathrm{CP}$, Osorio ML, Carvalho I, Faria T. How plants cope with water stress in the field. Photosynthesis and Growth. Annals of Botany. 2002;89: 907-916

16. Singh A, Kumar J, Kumar P. Effects of plant growth regulators and sucrose on post harvest physiology, membrane stability and vase life of cut spikes of gladiolus. Plant Growth Regul. 2008;55: 221-229.

17. Rabe AM, Aleiro BL, Maishanu HM, Maikudi HM. Influence of different water frequency on the growth and yield of Cymbopogon schoenanthus (camel grass). Asian Journal of Research in Agricultural and Forestry. 2018;1-15.

18. Naresh RK, Purushotam SP, Sigh Divivedi A, Vineetkumar. Effects of water stress on psychological process and yield attribute of different Mung bean (L) variated. African Journal of Biochemistry Research Academic Journals. 2013;7(5): 55-62.

Available:http://www.academicjournal.org/ AJBR.

19. Li Z, Waker S, Fischer BB, Nyogi KK. Sensing and responding to excess light. Annual Review of Plant Biology. 2009;60: 239-290.

20. Farooq M, Hussain M, Abdul Wahid, Siddique KHM. Plant response to drought stress. An overview, Morphological to molecular texture, Aroca (ed); 2012.

Available:http://www.springer.com/998364232652-3.

(c) 2019 Maishanu and Rabe; This is an Open Access article distributed under the terms of the Creative Commons Attribution License (http://creativecommons.org/licenses/by/4.0), which permits unrestricted use, distribution, and reproduction in any medium, provided the original work is properly cited.

Peer-review history:

The peer review history for this paper can be accessed here: http://www.sdiarticle4.com/review-history/51483 